\title{
Networking and Facework as Political Behavior within Organizations
}

\author{
[ Takuma Kimura ]
}

\begin{abstract}
In recent organizational studies, attention to organizational politics and political behavior has been increasing. This study explored the process of political behaviors within organizations using qualitative research of a sample of workers in Japanese firms. Through grounded theory approach, this study identified three constructs of political behaviors: (a) political use of non-political interpersonal networks, (b) leveraging social capital, and (c) other-face-saving behaviors. This study revealed the process of networking and the political use of interpersonal networks, which previous studies on political behaviors have not sufficiently investigated. Moreover, the results of this study can integrate the literature on political behavior and that of facework, which few prior studies have examined in the context of organizational politics.
\end{abstract}

Keywords-organizational politics, political behavior, networking, facework, social capital

\section{Introduction}

Traditional approaches in organizational studies assume that managers and employees make decisions in a rational or formal way. However, such an assumption does not necessarily reflect the reality of organizational behaviors (Narayanan \& Fahey, 1982). A more recent approach emphasizes the effect of members' political informal behaviors toward others on the organizational decision making (Tushman, 1977). Empirical studies based on this approach have identified various political behaviors, such as attacking others, ingratiation, impression management, and networking (e.g., Allen et al., 1979; Buchanan, 2008).

Although results of recent empirical studies indicated that networking is the core of political behaviors (see Kimura, 2015 for a review), few studied have examined how individuals conduct political networking. And surprisingly, few prior studies on political behaviors have considered facework (Goffman, 1955; Cocroft \& Ting-Toomey, 1994) - a type of informal interpersonal behavior that develops and maintains smooth interpersonal relationships-as a political behavior. Therefore, this study attempts to fill these gaps by examining how individuals conduct networking and facework as a political behavior.

Takuma Kimura

Hosei University

Japan

*Funding: This work was supported by JSPS KAKENHI Grant Number 15K17127.

\section{Literature Review}

Most studies in the 1990s had a negative perspective on political behaviors, considering them behaviors intended to enhance self-interest without regard to-or even at the expense of-organizational goals (e.g., Ferris et al. 1996). However, subsequent studies have treated organizational politics in more neutral ways. For example, KurchnerHawkins and Miller (2006) define organizational politics as "an exercise of power and influence that primarily occurs outside of formal organizational processes and procedures."'(p.331)

Recent studies regard organizational politics as an inherent part of organizational life, sometimes needed for the effective functioning of organizations (e.g., Blass \& Ferris, 2007; Ellen et al., 2013; Gunn \& Chen, 2006). Some empirical studies indicate that middle managers engage in political behaviors to effectively implement strategy formation, organizational change, and day-to-day operations (Hoon, 2007; Hope, 2010; Smith et al., 2009).

Networking is one of the most frequently mentioned behaviors in studies on political behavior (e.g., Treadway et al., 2010; Zanzi \& O'Neill, 2001). Empirical studies have suggested that political behaviors that effectively develop and use interpersonal networks enhance individual and team performance (Kimura, 2015). However, prior studies have not revealed how individuals develop and use such political networks.

Moreover, previous studies have regarded impression management as a main component of political behavior (e.g., Allen et al., 1979; Zanzi \& O'Neill, 2001). Impression management includes proactive impression management, which is intended to acquire a desired image, and defensive impression management, which is used to protect one's image (Ammeter et al., 2002).

Facework, a type of defensive impression management behavior (Ammeter et al. 2002), is "a set of communicative behaviors that people use to regulate their social dignity and support or challenge the other's social dignity" (TingToomey \& Kurogi, 1998, p.188). Facework, which includes diplomacy in interpersonal interaction (Goffman, 1955), can develop and maintain desirable interpersonal relationships. Thus, it is reasonable to regard facework as an important component of political behavior. However, surprisingly, few studies on political behavior have focused on facework (see Ammeter et al., 2002, for an important exception).

To narrow the research gaps noted above, this study addresses the following two research questions:

Research Question 1: How do individuals develop and use interpersonal networks as a political behavior within organizations?

Research Question 2: How do individuals engage in facework as a political behavior within organizations? 


\section{Method}

\section{A. Sample}

This study's sample comprises seven Japanese middle managers who work in Japanese firms and have a master's degrees in business administration or a related field. Middle managers are appropriate subjects for this study. Because of their position in the organizational hierarchy, they may engage in political behaviors in various directions (i.e. upward, lateral, and downward) (Smith et al., 2009; Wooldridge et al., 2008). Therefore, they can provide us with data about various political behaviors.

Graduates of business administration and related field are suitable subjects for this study, as they work a wide range of jobs, firms, and industries and are accustomed to talking about their personal experiences. Through personal networks, I accessed seven middle managers who have engaged in political behaviors. My sample was purposive in that I sought middle managers who had personally undertaken political behaviors. The jobs, age, and gender of respondents are shown in Table I.

TABLE I. OUTLINE OF THE CASES

\begin{tabular}{|c|c|c|}
\hline & $\begin{array}{r}\text { Interviewee: Job } \\
\text { Gender } \\
\text { Age }\end{array}$ & Situation \\
\hline Case A & $\begin{array}{l}\text { Business development } \\
30 \text { s } \\
\text { Female }\end{array}$ & Start-up of new business. \\
\hline Case B & $\begin{array}{l}\text { Research } \\
40 \mathrm{~s} \\
\text { Male }\end{array}$ & Start-up of new business. \\
\hline Case C & $\begin{array}{l}\text { Sales } \\
30 \text { s } \\
\text { Male }\end{array}$ & $\begin{array}{l}\text { Establishment of a corporate } \\
\text { venture. }\end{array}$ \\
\hline Case D & $\begin{array}{l}\text { Human Resource } \\
40 \mathrm{~s} \\
\text { Famale }\end{array}$ & $\begin{array}{l}\text { Planning and implementation } \\
\text { of a new training program. }\end{array}$ \\
\hline Case E & $\begin{array}{l}\text { Brand Management } \\
40 \mathrm{~s} \\
\text { Female }\end{array}$ & Product brand refinement. \\
\hline Case F & $\begin{array}{l}\text { Sales } \\
40 \mathrm{~s} \\
\text { Male }\end{array}$ & $\begin{array}{l}\text { Promoting employees in the } \\
\text { subsidiary to headquarters. }\end{array}$ \\
\hline Case G & $\begin{array}{l}\text { Sales } \\
40 \mathrm{~s} \\
\text { Male }\end{array}$ & $\begin{array}{l}\text { Acquisition of financial support } \\
\text { from the parent company for a } \\
\text { new project. }\end{array}$ \\
\hline
\end{tabular}

\section{B. Data Collection and Analysis}

In this study, I answered my research questions by closely examining respondents' political behavior narratives in a variety of business settings. To conduct exploratory analysis, I obtained rich data by conducting semi-structured interviews.

The interview question was broad: "Tell me your experience in which you made full use of political behaviors within the organization." To faithfully reflect the respondents' recognition of organizational politics and political behavior, I did not provide respondents with their specific definitions. Respondents mentioned symbolic events (e.g., business development) or day-to-day activities and told me their political behaviors in these situations. After each respondent had outlined his/her story, I asked him/her why he/she engaged in these political behaviors, to reveal his/her causes and purposes.
Interviews ranged from 80 to 100 minutes and averaged 90 minutes. All interviews were tape recorded, yielding over two-hundred pages of transcriptions. I analyzed the data using grounded theory coding methods (Corbin \& Strauss, 2007).

\section{Findings}

Each case illustrates political behaviors in various situations. Cases A and B are successful new business startups. Case $\mathrm{C}$ is a new corporate venture, where the respondent successfully established the business however subsequently lost his power. Case D involves the planning and implementation of a new training program that was at first not welcomed in the firm, however later was successful, attracting the subject's interest. Case E is a successful refinement of product brand. In Case F, a subsidiary's manager engaged in political behaviors to get his subordinates promoted. Finally, in Case G, a subsidiary's manager is attempting to draw financial resources for a new project from the parent company.

By closely examining the data for each case, I identified three common political behaviors: (a) political use of nonpolitical interpersonal networks, (b) leveraging social capital, and (c) other-face-saving behaviors. I explain these three behaviors below.

\section{A. Political Use of Non-Political Interpersonal Networks}

In all cases, respondents used their interpersonal networks that they had already developed without political intention (Table II). Although previous studies have regarded networking as a typical form of political behavior, our data showed that most of the respondents' networks were not deliberately and strategically developed for political purposes. Respondents did not refer to the development of such networks as political. Rather, they developed networks without considering political benefit but used them when they needed informal support from others. Contrary to these networks' development, respondents regarded their use as political.

For example, in Case C, a respondent's former immediate boss happened to have a good informal relationship with the person who held real power on corporate venture investment decision. In Case E, the person whom the respondent became familiar with in a past project, fortunately, became in charge of the research and development for the new brand. These cases illustrate that respondents developed interpersonal networks without political intentions but used them politically in situations where respondents need others' support. It suggests that the existence of such networks triggers respondents' political will (Mintzberg, 1985).

Only Cases A and D illustrate strategic networking with political intention. In these cases, respondents developed networks through the socializing outside of work to secure the cooperation of others. What is common in these cases is that respondents only recently joined the company. As they had no existing interpersonal networks within the company, they intentionally needed to develop networks. 
TABLE II. EXAMPLES OF POLITICAL USE OF NON-POLITICAL INTERPERSONAL NETWORKS

\begin{tabular}{|l|l|}
\hline & \multicolumn{1}{|c|}{ Example } \\
\hline Case A & a former team member \\
\hline Case B & $\begin{array}{l}\text { the immediate boss } \\
\text { team members" }\end{array}$ \\
\hline Case C & a former immediate boss \\
\hline Case D & a former immediate boss \\
\hline Case E & a former project member \\
\hline Case F & a contemporary \\
\hline Case G & a contemporary \\
\hline
\end{tabular}

\section{B. Leveraging Social Capital}

The second behavior commonly observed in all respondents is "leveraging social capital". Respondents did not use their social capital (Adler \& Kwon, 2002) just as it was for political influence. Rather, they leveraged their social capital by using a mediator, and his/her social capital, which usually was more influential than their own. More specifically, respondents did not engage in direct influence attempts (e.g., self-presentation, issue selling, and relationship building) toward authorities. Instead, they worked on others who had strong personal networks with the authorities and with whom respondents had already developed trusting relationships. They used these other individuals as mediators to influence the authorities (Table III).

TABLE III. EXAMPLES OF LEVERAGING SOCIAL CAPITAL

\begin{tabular}{|l|l|}
\hline & \multicolumn{1}{c|}{ Example } \\
\hline Case A & $\begin{array}{l}\text { She influenced the president through a trusting } \\
\text { colleague. }\end{array}$ \\
\hline Case B & $\begin{array}{l}\text { He influenced the executives through the } \\
\text { immediate boss. }\end{array}$ \\
\hline Case C & $\begin{array}{l}\text { He influenced the authorities through a former } \\
\text { immediate boss. }\end{array}$ \\
\hline Case D & $\begin{array}{l}\text { She made connection with a person with informal } \\
\text { power through trusting colleagues. }\end{array}$ \\
\hline Case E & $\begin{array}{l}\text { She influenced the senior managers through the } \\
\text { immediate boss. }\end{array}$ \\
\hline Case F & $\begin{array}{l}\text { He influenced the corporate executives through a } \\
\text { trusting contemporary. }\end{array}$ \\
\hline Case G & $\begin{array}{l}\text { He influence the corporate executives through a } \\
\text { trusting contemporary. }\end{array}$ \\
\hline
\end{tabular}

The data indicated that through mediators, respondents achieved a scope of political influence that would have been impossible to achieve if they directly worked on the authorities. For example, in Cases $\mathrm{F}$ and $\mathrm{G}$, respondents worked on their contemporaries who were in the executives' "in-group" (Dienesch \& Liden, 1986). In these cases, respondents asked their contemporaries to engage in political influence behaviors toward corporate executives to impact corporate decisions that would have been impossible to achieve if respondents had directly attempted to influence the executives.

Reliable individuals have greater political influence than those who are less reliable (Ammeter et al., 2002; Blickle et al., 2009). Therefore, if political actors have not developed trusting relationship with authorities, it is reasonable for them to use mediators, with whom they have already developed trusting relationships. The data showed that while all effective mediators had trusting relationships with authorities, most of them did not have any power on focal political issues. It suggests that such power is not necessary for an effective mediator.

\section{Other-Face-Saving Behaviors}

In every case, respondents engaged in facework mainly to save another's face rather than their own (Table IV).

TABLE IV. EXAMPLES OF OTHER-FACE SAVING

\begin{tabular}{|l|l|}
\hline & \multicolumn{1}{c|}{ Example } \\
\hline Case A & $\begin{array}{l}\text { She presented her own achievement as that of her } \\
\text { boss to save other units' member's face. }\end{array}$ \\
\hline Case B & $\begin{array}{l}\text { He made impression that he highly appreciated and } \\
\text { learned a lot from the evaluators. }\end{array}$ \\
\hline Case C & $\begin{array}{l}\text { He asked the authorities to explain about his work } \\
\text { to his boss. }\end{array}$ \\
\hline Case D & $\begin{array}{l}\text { The person with power and she concealed their } \\
\text { behind-the-scene activities. }\end{array}$ \\
\hline Case E & $\begin{array}{l}\text { She ingratiated toward the manager of the partner } \\
\text { company. }\end{array}$ \\
\hline Case F & $\begin{array}{l}\text { He reported frequently and openly to the } \\
\text { immediate boss. }\end{array}$ \\
\hline Case G & $\begin{array}{l}\text { He reported frequently and openly to the } \\
\text { immediate boss. }\end{array}$ \\
\hline
\end{tabular}

For example, in Case A, the respondent presented her achievement as that of her boss to other units' membersmost being senior to the respondent - because she was concerned that her outstanding achievement might cause these senior members to lose face. In Case B, regarding the feasibility of a new business, the respondent saved the face of evaluators by showing appreciation and saying how much he learned from them. In Case D, the respondent, along with a person with informal power, kept their behind-the-scene influence unknown to the formal decision maker.

These behaviors were intended to prevent the formal decision maker from feeling that his/her formal authority was a mere façade, which would have caused him/her to lose face. Each respondent engaged in these face-saving behaviors because he/she feared that if influential others were to lose face, they would resort to resistance and obstructionism as explicit or implicit retaliation.

In Case $\mathrm{C}$, the respondent neglected the opinion of the $\mathrm{CFO}$, and thus the CFO lost face. Later, when the CFO became the CEO, the respondent was pushed out and eventually demoted. It highlights the importance of facesaving behaviors.

\section{v. Discussion}

\section{A. Theoretical and Research Implications}

Examining the rich data that we obtained using qualitative research, this study identified three common political behaviors, largely overlooked by prior studies in this field.

First, in political situations, many respondents used interpersonal networks - developed not by political tactics but through long-term, day-to-day work at firms. They did 
not regard the development of such networks as a political behavior but did regard the use of them as a political behavior. Strategic and political networking were found only in cases where respondents had recently joined the firm and, thus, lacked in social capital.

Second, respondents used reliable mediators rather than attempting to influence directly the authorities. They leveraged their social capital by using people in their interpersonal network as mediators. One can achieve leveraging when mediators engaged in political behavior using their social capital, which was larger than that of the respondents. Such leveraging enabled respondents to achieve a greater influence that may be impossible to realize if they engaged in direct influence attempts.

Third, all the participants used facework to save the face of others. These behaviors were intended to prevent resistance and obstructionism.

In sum, this study reveals the process of networking and the political use of interpersonal networks, which previous studies on political behaviors have not sufficiently examined. Moreover, the results of this study integrate the literature on political behavior and that of facework, which few prior studies have examined in the context of organizational politics.

However, since the sample of this study is only Japanese workers, its findings might just reflect the characteristics of Japanese culture. Some previous studies indicated that Japanese society is more collectivistic than Western society (Hofstede, 1980; 2001). Thus, findings of the development and use of interpersonal networks might reflect behavioral attributes in a collectivistic culture. In such a culture, networking behavior toward influential others might be perceived as impudent and thus be avoided since acting by private wishes is not preferred in a collectivistic culture (Kim \& Nam, 1998; Liao \& Bond, 2011).

The findings of facework may also reflect behavioral attributes in a collectivistic culture. Face-negotiation theory suggests that members of collectivistic cultures tend to express a greater degree of other-face-maintenance messages than members of individualistic cultures (TingToomey \& Kurogi, 1998). Some empirical studies indicated that Japanese people tend to be concerned not only with their own "faces" but also with others (Lin \& Yamaguchi, 2011; Oetzel et al., 2001).

Therefore, it is not clear whether the behaviors identified in this study are generic or culturally unique. This newlygenerated question can extend the theoretical framework of international comparative studies of political behavior.

\section{B. Practical Implications}

The findings of this study have some practical implications. First, to be an effective decision maker, managers should understand the processes of political behaviors identified in this study. Understanding these processes can lead to better decision making in organizations.

Second, firms should include issues of informal networking and facework on the menu of their human development programs. Mentoring and coaching might be effective to develop political skill that enables one to engage successfully in such political behaviors (Blass \& Ferris, 2007; Ferris et al., 2005).

Third, if the findings of this study reflect the characteristics of Japanese culture, firms operating in Japan can take these findings into consideration in designing crosscultural education programs.

\section{Limitations and Future Research Directions}

As this study used only a Japanese sample and, thus, is not an international comparative study, we cannot determine whether the findings are unique to Japan or if we can generalize them to a broader society. Future international comparative studies will be able to answer this question.

Furthermore, although a grounded theory approach does not necessarily need a large sample (Guest et al., 2006), this study's sample is relatively small, and thus the analysis may not have reached theoretical saturation (Corbin \& Straus, 2007). Moreover, the data includes only one case of failure. By analyzing a larger sample, using a grounded theory approach, future research can discover constructs unidentified in this and previous studies and develop new theories that explain the causal relationship between those constructs.

\section{Acknowledgments}

I am especially grateful to all anonymous interviewees. I would also like to thank Natsuki Asai who helped me to create transcripts of interviews.

\section{References}

[1] Adler, P. S., \& Kwon, S. W. "Social capital: Prospects for a new concept." In Academy of management review, 2002, 27(1), 17-40.

[2] Allen, R. W., Madison, D. L., Porter, L. W., Renwick, P. A., \& Mayes, B. T. "Organizational Politics Tactics and Characteristics of Its Actors.” In California Management Review, 1979, 22(1), 77-83.

[3] Ammeter, A. P., Douglas, C., Gardner, W. L., Hochwarter, W. A., and Ferris, G. R. "Toward a political theory of leadership." In The Leadership Quarterly, 2002, 13(6), 751-796.

[4] Blass, F. R., \& Ferris, G. R. "Leader reputation: The role of mentoring, political skill, contextual learning, and adaptation.”, In Human Resource Management, 2007, 46(1), 5-19.

[5] Blickle, G., Kramar, J., Zettler, I., Momm, T., Summers, J. K., Munyon, T. P., and Ferris, G. R. "Job demands as a moderator of the political skill-job performance relationship." In Career Development International, 2009, 14(4), 333- 350.

[6] Brouer, R. L., Douglas, C., Treadway, D. C., and Ferris, G. R. "Leader political skill, relationship quality, and leadership effectiveness a two-study model test and constructive replication." In Journal of Leadership \& Organizational Studies, 2013, 20(2), 185198

[7] Buchanan, D. A. "You stab my back, I'll stab yours: Management experience and perceptions of organization political behaviour." In British Journal of Management, 2008, 19(1), 49-64.

[8] Cocroft, B. A. K., and Ting-Toomey, S. "Facework in Japan and the United States." In International Journal of Intercultural Relations, 1994, 18(4), 469-506.

[9] Corbin, J., and Strauss, A. L. Basics of qualitative research: Techniques and procedures for developing grounded theory. San Francisco: Sage, 2007

[10] Dienesch, R. M., and Liden, R. C. "Leader-member exchange model of leadership: A critique and further development." In Academy of management review, 1986, 11(3), 618-634. 
[11] Ellen III, B. P., Ferris, G. R., and Buckley, M. R. "Leader political support: Reconsidering leader political behavior." In The Leadership Quarterly, 2013, 24(6), 842-857.

[12] Ferris, G. R., Frink, D. D., Galang, M. C., Zhou, J., Kacmar, K. M., and Howard, J. L. "Perceptions of organizational politics: Prediction, stress-related implications, and outcomes." In Human relations, 1996, 49(2), 233-266

[13] Ferris, G. R., Treadway, D. C., Kolodinsky, R. W., Hochwarter, W. A., Kacmar, C. J., Douglas, C., and Frink, D. D. "Development and validation of the political skill inventory." In Journal of Management, 2005, 31(1), 126-152.

[14] Goffman, E. “On facework.” In Psychiatry, 1955, 18, 213-231.

[15] Guest, G., Bunce, A., and Johnson, L. "How many interviews are enough? An experiment with data saturation and variability." In Field methods, 2006, 18(1), 59-82.

[16] Gunn, J., and Chen, S. "A micro-political perspective of strategic management." In Vigoda-Gadot, E., \& Drory, A. (Eds.), Handbook of Organizational Politics: Organizational Politics. 2006, pp.209-229. Edward Elgar Pub.

[17] Hofstede, G. "Motivation, leadership, and organization: do American theories apply abroad?." Organizational dynamics, 1980, 9(1), 42-63.

[18] Hofstede, G. H. Culture's consequences: Comparing values, behaviors, institutions and organizations across nations. Sage, 2001

[19] Hoon, C. "Committees as strategic practice: The role of strategic conversation in a public administration." In Human Relations, 2007, 60(6), 921-952

[20] Hope, O. "The Politics of Middle Management Sensemaking and Sensegiving." In Journal of Change Management, 2010, 10(2), 195215.

[21] Kim, J. Y., and Nam, S. H. "The concept and dynamics of face: Implications for organizational behavior in Asia." In Organization Science, 1998, 9(4), 522-534.

[22] Kimura, T. "A Review of Political Skill: Current Research Trend and Directions for Future Research." In International Journal of Management Reviews, 2015, 17(3), 312-332.

[23] Kurchner-Hawkins, R. and Miller, R. "Organizational Politics. Building Positive Political Strategies in Turbulent Times." In E. Vigoda-Gadot and A. Drory (eds.), Handbook of Organizational Politics (Edward Elgar, Cheltenham, UK), 2006, pp. 328-351.

[24] Leary, M. R., and Kowalski, R. M. "Impression management: A literature review and two-component model." In Psychological bulletin, 1990, 107(1), 34-47.

[25] Liao, Y., and Bond, M. "The dynamics of face loss following interpersonal harm for Chinese and Americans." In Journal of CrossCultural Psychology, 2011, 42(1), 25-38.

[26] Lin, C. C., and Yamaguchi, S. "Effects of face experience on emotions and self-esteem in Japanese culture." In European Journal of Social Psychology, 2011, 41(4), 446-455.

[27] Mintzberg, H. Power in and around organizations. Englewood Cliffs, NJ: Prentice-Hall, 1983.

[28] Munyon, T. P., Summers, J. K., Thompson, K. M., and Ferris, G. R. "Political Skill and Work Outcomes: A Theoretical Extension, Meta - Analytic Investigation, and Agenda for the Future." In Personnel Psychology, 2015, 68(1), 143-184.

[29] Narayanan, V. K., and Fahey, L. "The Micro-Politics of Strategy Formulation1." In Academy of Management Review, 1982, 7(1), 2534.

[30] Oetzel, J., Ting-Toomey, S., Masumoto, T., Yokochi, Y., Pan, X., Takai, J., and Wilcox, R. "Face and facework in conflict: A crosscultural comparison of China, Germany, Japan, and the United States." In Communication Monographs, 2001, 68(3), 235-258.

[31] Smith, A. D., Plowman, D. A., Duchon, D., and Quinn, A. M. "A qualitative study of high-reputation plant managers: Political skill and successful outcomes." In Journal of Operations Management, 2009, $27(6), 428-443$.

[32] Ting-Toomey, S., and Kurogi, A. "Facework competence in intercultural conflict: An updated face-negotiation theory." In International journal of intercultural relations, 1998, 22(2), 187-225.

[33] Treadway, D. C., Breland, J. W., Adams, G. L., Duke, A. B., and Williams, L. A. "The interactive effects of political skill and future time perspective on career and community networking behavior." In Social Networks, 2010, 32(2), 138-147.
[34] Tushman, M. L. "A political approach to organizations: A review and rationale." In Academy of Management Review, 1977, 2(2), 206-216.

[35] Wooldridge, B., Schmid, T., and Floyd, S. W. "The middle management perspective on strategy process: Contributions, synthesis, and future research." In Journal of management, 2008, 34(6), 1190-1221.

[36] Zanzi, A., and O'Neill, R. M. "Sanctioned versus non-sanctioned political tactics." In Journal of Managerial Issues, 2001, 13(2), 245262

\section{About the Author:}

Takuma Kimura is an associate professor at Hosei University. His research focuses on organizational politics, political behaviors, and political skill. His papers have appeared in prominent academic journals such as International Journal of Management Reviews and Journal of Business Ethics. 